\title{
8 \\ Entry into the WTO: commitments and implementation
}

\section{Geoff Raby}

Accession to the WTO is a major undertaking for any country. As with all treaties, countries must adjust domestic laws and regulations to bring themselves into conformity with their international obligations. In most cases, this is a difficult exercise involving complex political choices. As in the general case of trade liberalisation, over time all will benefit from the welfare gains from WTO membership, but in the short to medium term, income redistribution between groups in society is likely to take place. In other words, during the adjustment period, there will be winners and losers.

Managing the political economy of this process is difficult enough at the best of times. With the inevitably protracted negotiating process involved in WTO accession, this is all the more difficult to manage. Interest groups have plenty of lead time to work out what the implications of the proposed new obligations will mean for them and time to muster political support to head off unfavourable decisions.

Add to this the unique and legally binding nature of the WTO agreements, and the fact that some 140 or so countries need to reach mutually satisfactory results with the aspiring member, and it thus becomes a marvel of modern multilateral diplomacy that these days anyone can manage to join the WTO at all. In a country of China's domestic political complexity, with an economy still somewhere between plan and market, and with an international relations agenda that stresses China's independence from outside influence, China's accession to the WTO at the end of 2001 is a remarkable achievement for the international system. 
In trying to understand the commitments that China has entered into and what implementation may mean - though it is far too early to judge this with any certaintyit is necessary to know something of the negotiating history that led to the package of undertakings on which China's accession is based. The ebb and flow of the negotiations over so many years shaped the final balance of compromises made both by China and existing WTO members.

\section{A SKETCH OF THE NEGOTIATING HISTORY}

The full history of the negotiations is yet to be written, but it would be an endeavour well worth pursuing. It is a tale of the evolution of two systems and how their respective developments intersected at various points until they eventually meshed at the time of China's accession.

China initially advised its intention to 'resume' its status as a 'Contracting Party' of the GATT in 1986. China had been one of the 23 original parties to the GATT in 1948 , but after the revolution the government in Taiwan withdrew China's membership. As Beijing had never recognised this act by Taipei, much of the earliest period of China's efforts to join the GATT was largely a political discussion about whether China was 'resuming' its membership or seeking to 'accede'. This was largely an argument between Beijing and Washington. Although, at one stage in the early years, Japan began to insist that if China intended to 'resume' its membership rather than accede anew, then Beijing should be required to pay all past membership fees owed since 1947.

Over the subsequent 16 years of negotiations there may well have been times when officials in Beijing had wished they had been allowed simply to pay their past subscriptions and get on with their membership. In reality, that would have been neither a sufficient nor a desirable basis on which to decide on membership. This anecdote, however, does serve to underscore the confusion that often surrounded China's quest to enter the GATT and later the WTO. This confusion applied both to China's own approach as well as to the existing members trying to come to grips with an accession of China's size, especially in view of the fact that reform of the economic system was in its infancy and political commitment to the process was so uncertain.

In China's accession negotiations three periods stand out. First is the period of ambivalence, from 1986 until the Tian An Men Square events. Second is the period of estrangement following Tian An Men Square and lasting until 1995, when China applied 
to join the WTO. Third, the period of gradual mutual accommodation between China and existing WTO members, eventually leading to accession at the end of 2001.

Characteristic of the period of ambivalence is the debate discussed above over whether China was resuming membership or acceding. Such political concerns are really irrelevant for accession, which involves negotiating a contractual basis for membership. The fact that these political discussions were so dominant at the time reflected the political uncertainty within China over GATT membership at such an early stage in its economic reforms. It also reflected the uncertainty among contracting parties as to China's intentions. It is likely that China's initial interest in joining the GATT was driven mainly by foreign policy concerns to normalise China's international relations. The same imperatives led China into the World Bank, IMF and other international bodies. To be a great power, China had to take its place in the major international institutions, including, at the time, the GATT.

Nevertheless, during this period, useful work was done both in starting the long process of educating Chinese politicians and officials about the GATT system and in developing skills among China's negotiators. As early as 1986, under a bilateral aid program, Australia had placed an experienced trade lawyer in China's Ministry of Foreign Economic Relations and Trade MOFERT (forerunner of the Ministry of Foreign Trade and Economic Cooperation) to provide technical training and help start the process of drafting China's first information submission on which subsequent negotiations were based. Such aid continued throughout the process.

By the time of the Tian An Men Square massacre, little substantive progress had been made on China's accession to the GATT, despite continued substantial advance in China's domestic economic reforms and opening to the international economic system. The political turmoil of Tian An Men Square did not stem the domestic reforms or the ever deepening engagement with the international economy through increasing trade and investment flows. Meanwhile, the Uruguay Round of trade negotiations had been launched some months after China's GATT bid but was badly stalled by mid 1989. Ambivalence had turned to neglect on all sides.

Prior to June 1989, China's accession was becoming dormant. With the events of June 1989, and the subsequent political reaction in China, political attitudes hardened towards China among many in the West. China's accession now attracted highly charged political interest both within China and from many outside. On one hand, accession became a test of the international legitimacy of the post-Tian An Men regime and, on the other, part of the international reaction to events in China. With 
the rapid growth of China's exports during the early 1990s, particularly to highincome markets, the issues of moral concern and trade protection became increasingly entwined.

During this period of estrangement, China approached the negotiations largely as a test of its international weight and as a measure of its emergence as a major world power. Whereas negotiations for GATTMTO membership required agreement to be reached, at least in principle, with all members individually, China seemed to approach the negotiations as a test of will mainly between it and Washington and to a lesser extent Brussels. The smaller players, including Australia, were essentially sidelined during this time. China's negotiating strategy was to cut a deal with the United States and the European Union and then expect all other members to sign up to it. While there will always be a substantial element in any GATT/WTO negotiation of the majors doing a deal and then presenting it to the rest, the views of other members do have to be taken into account. At this time, China politely met with the smaller players, bilaterally and as part of the regular visits to Geneva for Working Party meetings, but it was not engaging seriously with them.

While China played superpower politics with its accession, the goal posts shifted. Not, as was often claimed, because the United States or other major negotiating partners had changed their positions unilaterally, although there was inevitably an element of this, but because the system China was seeking to join had itself changed fundamentally. With the conclusion of the Uruguay Round, the GATT was replaced by the WTO in 1995. From early in the 1990s it was increasingly evident that acceding countries would have to take on a range of obligations in new and challenging areas that had not existed under the GATT. The negotiations for the Uruguay Round were completed in December 1993 and from that time on acceding to the WTO system would require much more from China than under the old GATT.

With the formation of the WTO, whole new areas had to be negotiated covering services, intellectual property, agriculture, sanitary and phytosanitary measures and trade-related investment measures. At the same time, the negotiations had produced higher levels of commitments for liberalisation on a much wider range of products than ever before. A further significant complicating factor had also now entered the negotiations over China's (and everyone else's) accession and that was the new Dispute Settlement Body. This had far more power to enforce obligations and authorise retaliatory measures than under the old GATT. Henceforth, all negotiations took on a much more cautious, legalistic character for all parties. 
China made one last bid for membership on political grounds. It sought to rally international support and sympathy for its becoming a founding member of the WTO in 1995. It garnered a great deal of political support and the pressure on members to cut a quick and dirty deal was immense. China's offer did not meet the commercial interests of WTO members and, as with other deadlines before, China's accession was missed and the world was still the same the next morning.

After this, China's approach to negotiating its accession shifted in steps towards serious engagement, not only with the majors but, importantly, with the multitude of smaller members as well. China set about accommodating itself to the WTO, and other members to China's eventual accession on mutually acceptable terms. By this time, China was also well versed in the functioning of the WTO and had assembled an impressive team of negotiators. The negotiations were still difficult and sometimes highly fraught up until the end. Eventually, incremental progress resulted in a package of commitments as the legal basis of China's accession to the WTO.

\section{COMMITMENTS}

Unlike negotiations during a multilateral round, such as the current Doha Round, accession negotiations are non-reciprocal. An aspiring entrant is required to adjust its levels of protection to match those that generally apply for existing members at similar levels of development. The reasoning is that existing members have already 'paid' each other for the prevailing liberalisation extended to each other and new members are required to do the same.

The emphasis on reciprocity in the GATTMTO system is a major factor contributing to its stability and success but stands in sharp contrast to the economist's approach to liberalisation. Economists argue that countries liberalise because it is good for them to do so. With its voluntarism, APEC's approach to liberalisation is rather more like that of the economist than the trade negotiator.

WTO accession negotiations fall into two broad parts. One involves market access negotiations. These are essentially bilateral negotiations with individual members, or groups of members with a specific shared market access interest. The other part deals essentially with the domestic regulatory adjustments that must be made by the acceding member to bring its trading and related practices into conformity with WTO rules, including on subsidies.

Market access is the classic trade negotiation. It deals essentially with barriers at the border such as tariffs and tariff-rate quotas (TRQs) and non-tariff barriers. Since 
the creation of the WTO, it also includes negotiations on services. These involve domestic regulatory reforms to increase access to the domestic market for foreign services suppliers. All members of the WTO share in the results on the basis of the most-favoured nation principle; that is, one member is not allowed to discriminate against other members in terms of access to its market.

\section{MARKET ACCESS}

While negotiations are conducted on an individual tariff line basis, these may be summarised as follows.

In agriculture, China has agreed to average tariff cuts on most products from 23 per cent to 15 per cent, to be phased in by 2004 , albeit with considerable variation around the mean. All tariffs are bound. These cuts comprise a TRQ system for imports of bulk commodities, which is of particular value for products of interest to Australia, such as wool, sugar, wheat, rice, cotton and vegetable oils. The TRQ will provide guaranteed levels of increasing access at relatively low tariff levels.

China has also agreed to an administrative system for its TRQs which should help preserve their value to potential exporters to China. This includes increasing the share of TRQs available to private traders.

An additional commitment of major future value for agricultural exporters was agreement not to use export subsidies. Negotiations for this commitment were particularly tough. Whether or not China would at some stage have been in a position to subsidise agricultural exports is questionable, but the commitment is of important strategic and political, as well as commercial, advantage as efficient agriculture exporters seek to end all export subsidies. Similarly, China has agreed to limit tradedistorting domestic support to less than that normally available to developing countries.

For industrial products, average tariffs with few exceptions will be cut from 17 per cent to 8.9 per cent by 2005. All tariffs will be bound. Of course, there is considerable variation around this average as well, with industrial tariffs ranging from 0 per cent to 47 per cent. The remaining few quotas on industrial products will be eliminated by 2005. China has also undertaken to eliminate all export subsidies for industrial products, which was a long-standing requirement under the GATT Subsidies Code, strengthened in the Uruguay Round.

Services involved some of the most difficult negotiations of all, and this sector was the last to be settled. Much of the negotiation concentrated on four major areas: telecoms, banking and insurance, professional services, and distribution. 
Telecoms negotiations were particularly sensitive in view of the government's perception of the critical political function played by its existing regulatory regime in this area. The commitments involve a gradual expansion of access up to 2005. In the first phase, foreign suppliers will be permitted to establish joint-venture enterprises without quantitative restrictions in several cities but with foreign equity restricted to 25 per cent. Over the next three years, the areas open to foreign investment will gradually be expanded and equity limits raised to a maximum of 49 per cent. By 2005 all geographic restrictions will be removed.

On accession, foreign banks are to be permitted to provide foreign currency services without restrictions on clients. By 2004, foreign banks will be allowed to provide local currency services to Chinese enterprises. Within five years of accession, foreign financial institutions can extend this to all Chinese clients. Geographic restrictions will be phased out.

Foreign non-life insurers will be permitted to establish joint ventures with 51 per cent foreign ownership and within two years following accession wholly foreignowned subsidiaries will be allowed. In the case of life insurers, on accession 50 per cent joint-ventures will be permitted. Many other classes of insurers will be allowed to increase foreign equity from 50 per cent to 100 per cent over the next five years. Similarly, geographic restrictions will be phased out.

In the distribution sector, China will liberalise wholesale and retailing services for most products, including imported products, throughout China within three years.

Outside these sectors, geographic and numerical restrictions on foreign accountancy, legal and architecture service providers will be phased out. National treatment for foreign accountants will apply to those who have passed their Chinese CPA examinations. Foreign architect firms will be able to have majority ownership in joint ventures.

\section{SYSTEMIC COMMITMENTS}

While China's market access commitments are significant in every respect and will substantially increase China's integration into international markets, the commitments that touch on the fundamental structure of China's half-way house economic system promise to be the most profound aspect of its WTO accession. Advocates of economic reform in China have long argued for GATT/WTO membership as the surest way to lock in the reform process and to push it further into areas of deep political resistance. 
Within three years of entry, all enterprises will have the right to import and export any goods and trade them throughout China with limited exceptions.

China will retain state trading for a small range of products, including grains, cotton and sugar, but state trading enterprises will be required to act solely in accord with commercial considerations. For some products, private traders will be able to conduct an increasing share of imports.

China will progressively eliminate designated trading restrictions for wool and steel over three years.

Foreign exchange and trade balancing requirements, local content and export performance requirements will no longer apply to foreign or joint venture firms.

China will eliminate dual pricing practices as well as differences in treatment accorded to goods produced for sale in China in comparison with those produced for export. Price controls will not be used to provide protection.

China will reform its standards, technical barriers, conformity assessment procedures, and sanitary and phytosanitary regimes to conform with WTO requirements.

China will enhance protection of intellectual property rights.

\section{THE ADDITIONAL CONDITIONS}

China's size in terms of share of world markets, especially in some products like textiles, and the structure of its economic system led to a number of additional and unique conditions being attached to China's accession. These conditions, because they were special, were politically difficult for China to accept. They had their origins deep in the negotiating history of China's accession, particularly the initial ambivalence of both China and members to its accession and the subsequent period of estrangement.

A special Transitional Product-Specific Safeguard Mechanism will be available to WTO members for 12 years where imports from China cause or threaten disruption in the domestic market. A Textiles Safeguard will be available to WTO members to avoid market disruption until the end of 2008. WTO members will be able to continue to use non-market economy methodology to determine price comparability in antidumping cases.

China will increase transparency through publication of laws and regulations, establish impartial independent processes for review of administrative decisions, and uniformly administer the trade regime across China. 
China will submit to an annual review by the WTO of its implementation for a period of eight years, with a final review in the tenth year.

\section{Implementation}

The accession package that China now has to implement represents the result of hard fought compromises. The final package is also based on strong commitment to the continuation of fundamental reform of the Chinese economy. Indeed, accession may not have been possible until China's reforms and economic development had reached their current stage and sufficient political will had coalesced around their extension.

China has begun to take steps towards implementing its commitments and is preparing the way politically. China's accession to the WTO has been given almost as much national publicity and fanfare as its securing the right to host the 2008 Olympic Games. A visitor to Beijing after late 2001 would have been struck by the billboards hailing China's WTO accession. It may be that a larger share of the Chinese population has heard of the WTO than would be the case in Australia. The political seriousness of Beijing's approach to membership at this stage is very encouraging.

As with the negotiations, so it will be with implementation. Pressures are likely to arise domestically to trim and hedge on commitments. China at times is likely to disappoint other members in its implementation. At times this may be justified, at others not. Nothing in this would be unique to China's implementation of its commitments following accession. Other countries often struggle with their implementation following accession. China's sheer weight in a number of key sectors in international trade will, however, be likely to draw greater attention from trading partners than may occur for smaller members. The complexity of China's commitments, especially those involving systemic areas of reform, is also likely to lead to unrealistic expectations at times. This could increase dispute settlement actions and, unless restraint is shown, will place the still evolving Dispute Settlement Body under greater strain. Ultimately, China's continuing adherence to its economic reform policies will be the most sustainable guarantee of satisfactory implementation of its WTO commitments.

China's implementation will be monitored closely by other members. The realisation of the expected benefits for existing members from China's accession will depend on how completely China meets its commitments. It will therefore be in members' interests to work closely with China on implementation, especially by providing technical support to help it deliver on its commitments. 


\section{SOME CONCLUDING REFLECTIONS}

China's accession to the WTO has been largely a result of its two-decade long persistence with reform of its economic system and the resulting growth in its level of development. As a consequence of accession to the WTO, the reform policies are now entrenched in binding, legally enforceable, international treaties. WTO accession will therefore help to sustain further reform. This outcome has been possible because China's accession was a high quality one as set down in its package of commitments. A quick and dirty political fix, if one had ever really been possible, could have harmed China's reform and would certainly have harmed the WTO. Nonetheless, over time, China's membership will also have profound implications for the character and functioning of the WTO itself. The evolving symbiotic relationship between China and the GATT/WTO system which began in 1986 has now entered a new and important phase. 